\title{
HVORDAN LAGE ET SAMMENDRAG?
}

Sammendraget er gjerne det forste som blir lest og vurdert en vitenskapelig tekst.

\section{Tekst: Anners Lerdal}

De vanligste grunnene til at man lager et vitenskapelig sammendrag, ofte kalt abstrakt, er at man ønsker presentere en forskningsstudie pa en konferanse elle mendraget er noe av det første som blir lest og vurdert. Rammene er ofte satt til kun 150-300 ord, derfor bor teksten være godt gjennomarbeidet for at budskapet skal nà frem og at man skal lykkes. Hvis konferansebidraget eller artikkelen blir antatt, er naturtigvis sem heste som blir lest. Noen neyer seg kanskje met det. Teksten bor derfor pirre leserens nysgerighed dett Sevite mer om prosjektet elter lese mer av arikketer. Videre bor sammendraget ha et konkret innhold og.

For å bli antatt er det selvfølgelig viktig at in tidsskriftets formål I utforming av sammendraget er bade oppbyggingen (strukturen) og innholdet viktig. Dfte har konferansearrangøren eller tidsskriftet laget retningslinjer for utformingen. Disse følger stort se og konklusjon.

$>$ BAKGRUNN

Dette avSnittet består ofte av en til tre setninger hvor studiens problemstilling settes inn $i$ en større samselt nyt. Mad studien, at fenomenet ikke er beskrever idligere, at fenomenet ikke har vært studert i denne populasjonen, at utvalget er spesielt Ifor eksempel svært representativt) eller at designet (forskningsopplegget) som er brukt er godt egnet til å besvar 列 teste hypotesene.

$>$ HENSIKT

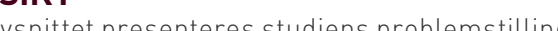

forskningsspørsmål eller hypoteser på en kortfatte mate, ofte kun i en eller to setninger. Gjennom formuleringen av studiens hensikt angir manogså indirekte gennom or av forskningsopplegget, for eksempel ger. beskrivetser av hurdan et fenomen oppleves. titative beskrivende studier innebærer abeskriver at man undersøker forekomster av en elter flere titstander eller egenskaper. Studier av utforskende karakter rapporterer gierne sammenhenger mellom fenomener og tilstander som studeres.

\section{$>$ METODE}

D E pel er kvatitativt forskningsopplegg, en tverrsnitts(for eksempel fokudiel og metodene som er bruk spørreskjemal. Videre beskrives hvordan deltakere til utvalget er rekruttert og eventuelt andre kilder man har hentet data fra. Hvis studien har et kvalitativt forskningsopplegg, velger noen forfattere også å oppgi handan data er anatysert. loversiktsartikter oppgir man ofte hva som er grunnlagsmaterialet og hvordan dette er innhentet lfor eksempel ved bruk av særskilt

\section{$>$ RESULTAT} 作 resultatene.

\section{$>$ KONKLUSJON}

så?» Altså, hvilke konsekvenser har kunnskapen som er fremkommet studien samt resultater av annen forskning for klinisk praksis, videre forskning og/eller teoriutvikling. Konsekvensene man oppgir må være fullt ut underbygfunn kandiens funn. Selv om studien viser til klare svakheter i forskningsopplegget. Av den grunn kan det

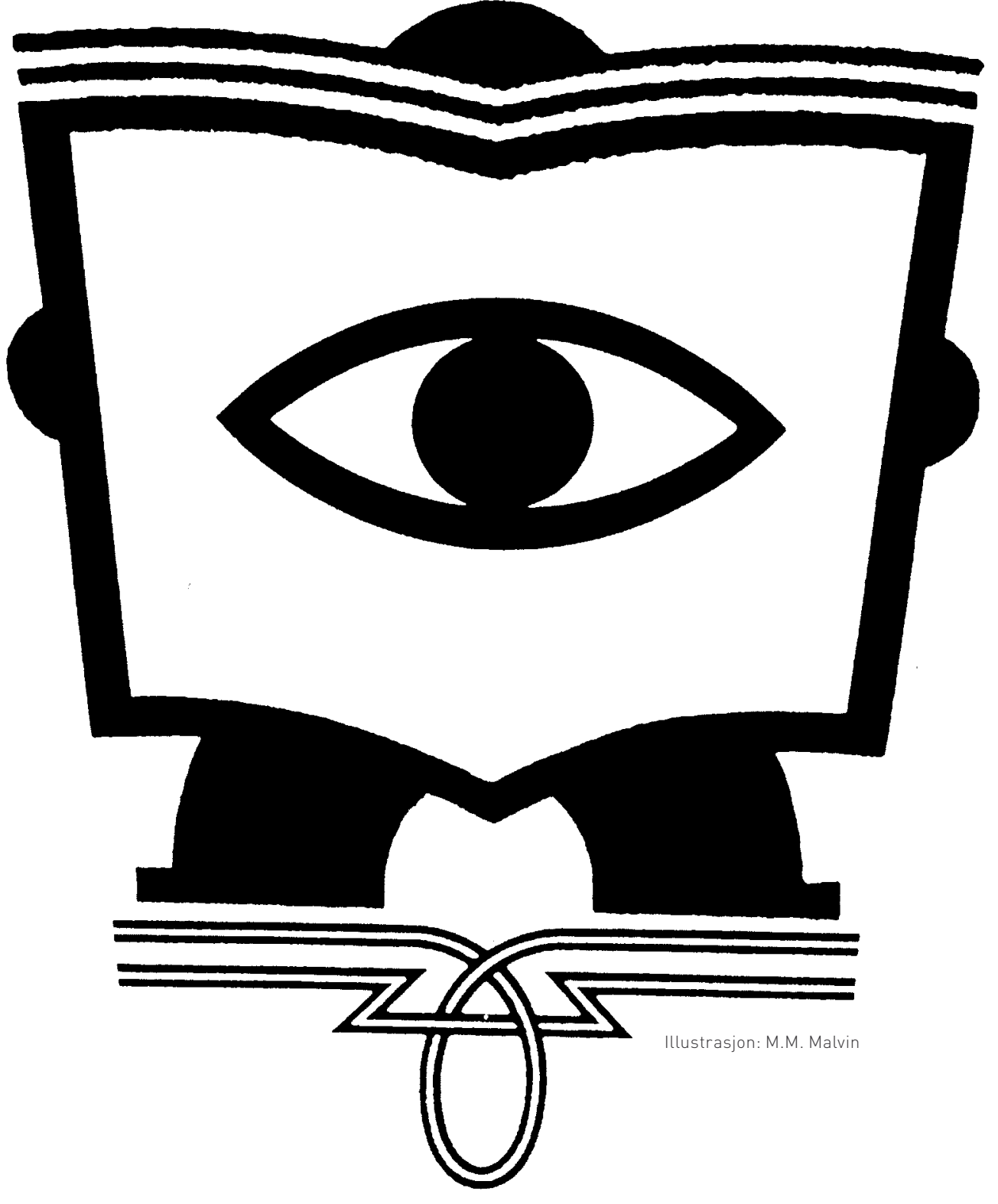

være nødvendig å anbefale gjennomføringen av samme LITTERATUR studieopplegg (replikasjonsstudie) eller å undersøke torskningsspørsmatene ved hjetp av andre metoder for a avkrefte eller finne støtte for sammenhenger man har funnet. Noen tidsskrift ønsker ingen egen «konPolit DF. Beck CT. 2008 Nursing research - Generating and
Assessing Evidence for Nursing Practice. 8. ed. Philadelphia, Pa. ir en fortolkning av funnene. 